\title{
A NOTE ON THE METABOLIC CRITERIA OF HYPERPARATHYROIDISM
}

\author{
By CLARENCE L. ROBBINS 1 AND DAVID M. KYDD \\ (From the Department of Internal Medicine, Yale University, New Haven)
}

(Received for publication October 20, 1934)

As might be anticipated the identification of parathyroid hyperfunction as the cause of osteitis fibrosa cystica $(21,30)$ has occasioned many attempts to indict the parathyroid glands in other malacic diseases of the bone. The controversy in the literature regarding the use of parathyroidectomy in the treatment of various disorders of the skeletal system would seem to be ample testimony that the possible rôle of the parathyroids in causing diseases associated with disturbances of calcification is not yet clearly defined $(3,4,5,6,7,15)$. In the opinion of some writers apparently, backache and some $\mathrm{x}$-ray evidence of demineralization of the vertebrae are sufficient grounds for the diagnosis of "parathyroidism" and the procedure of parathyroidectomy. The more critical school has maintained that hyperparathyroidism is a distinct clinical entity usually associated with adenoma of parathyroid tissue and characterized by a definite disturbance of calcium and phosphorus metabolism. Certain metabolic criteria have been proposed which are:

1. Hypercalcemia, usually with hypophosphatemia.

2. Excessive excretion of calcium and phosphorus.

3. Increased retention of calcium with high phosphorus intake.

Frequently it is implied that some one or all of these criteria must be satisfied before a diagnosis of hyperparathyroidism may be made; occasionally the statement is made that the laboratory findings are "pathognomonic" of the disease (15).

The present communication does not pretend to settle the controversy regarding etiologic relationships; original data are submitted simply to emphasize the hazards of entertaining any notions that the biochemical findings in diseases of the skeleton can suffice to establish a diagnosis.

\footnotetext{
${ }^{1}$ Sax Fellow in Clinical Medicine.
}

\section{METHODS}

Protocols of the cases studied are appended. Cases 1, 2 and 3 were diagnosed myelomatosis; in Case 1 the diagnosis was confirmed by autopsy, in Cases 2 and 3 by biopsy of excised bone. Case 4 presented the clinical picture of Paget's disease of the bones and this diagnosis was confirmed at autopsy.

The patients, all males, were studied on the medical wards of the New Haven Hospital. The diets were specially prepared in the diet kitchen of the hospital and the usual precautions required for careful balance studies were observed. In Case 1, since varied diets were given, the intakes of calcium and phosphorus were calculated from Sherman's tables (36). In Cases 2, 3 and 4 a constant intake was insured by giving an identical diet on every day of the experiment as well as during a three-day fore-period. At frequent intervals duplicate diets were analyzed for calcium, phosphorus and nitrogen. The actual and calculated values for calcium and phosphorus in the low calcium diets agreed within $5 \mathrm{mgm}$. for 24 hours. In the high calcium diets the analytical values were lower than the calculated figures by 2.3 per cent for calcium and 7.3 per cent for phosphorus. The acid-base values of the diets were essentially neutral.

In Cases 2 and 4 the excreta were collected in periods of three days each; in Case 3 the periods were 4 days each; a few periods in Case 1 were longer. The principles of the ward routine and methods closely followed those described by Bauer and Aub (9). In the collection, separation and preservation of specimens the usual careful techniques were employed. Daily analyses for creatinine served as checks on the completeness of urine collections.

The wet stools for each period were mixed according to a method used in this laboratory (26). Weighed aliquots of urine and stools were ashed in a muffle furnace at $600^{\circ} \mathrm{C}$. Calcium was precipitated as the oxalate from acid extracts of the 
ash at a $\mathrm{pH}$ between 4 and 5 . After standing overnight the salt was filtered off on fritted Jenaglass funnels, washed with dilute ammonia water, dissolved in sulphuric acid and the oxalate was determined by titration with $0.05 N$ potassium permanganate. Phosphorus was precipitated from the extract of the ash as magnesium ammonium phosphate. After cooling, shaking for five minutes and allowing to stand overnight, the salt was transferred quantitatively to weighed Gooch crucibles and ignited in the muffle furnace at $600^{\circ} \mathrm{C}$. for one hour. After drying in the desiccator the crucibles containing magnesium pyrophosphate were reweighed. The accuracy of the methods for calcium and phosphorus in the excreta was frequently checked by analyses of known solutions. The maximum error was 3 per cent.

Serum calcium was determined by a modification of the Kramer-Tisdall method (20) and serum phosphorus by the Fiske and Subbarow method (17). Serum proteins were determined by the previously described method in use in this laboratory (12).

\section{RESULTS}

The detailed studies of each case are recorded in Tables I to IV. To facilitate comparison with

TABLE I

Calcium and phosphorus balance. (Case 1, J. B. Diagnosis: Multiple myeloma)



* 2.82 grams $\mathrm{P}$ per three-day period added as $\left(\mathrm{NH}_{4}\right)_{2} \mathrm{HPO}_{4}$.

TABLE II

Calcium and phosphorus balance. (Case 2, A.C. Diagnosis: Multiple myeloma)

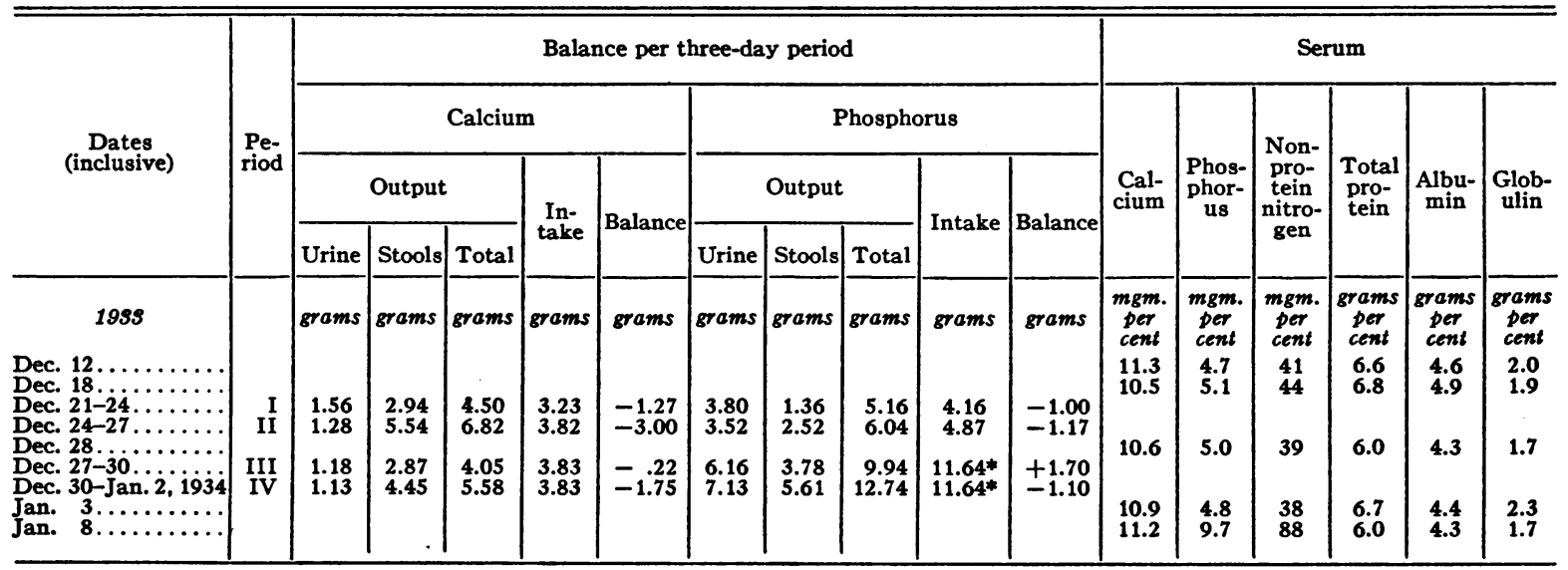

* 6.72 grams $\mathrm{P}$ per three-day period added as $\mathrm{NaH}_{2} \mathrm{PO}_{4} \cdot \mathrm{H}_{2} \mathrm{O}$. 
TABLE III

Calcium and phosphorus balance. (Case 3, F. A. Diagnosis: Multiple myeloma)

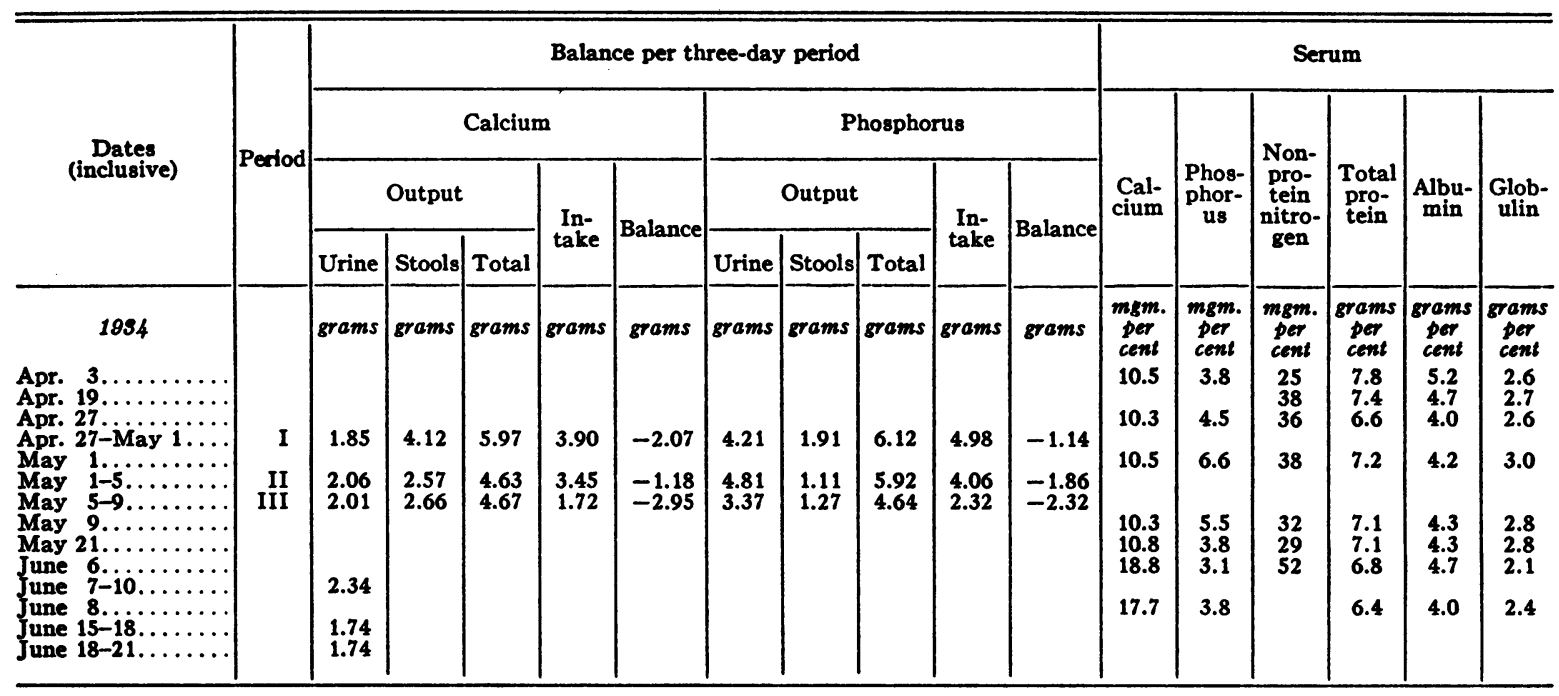

TABLE IV

Calcium and phosphorus balance. (Case 4, W. C. Diagnosis: Paget's disease)

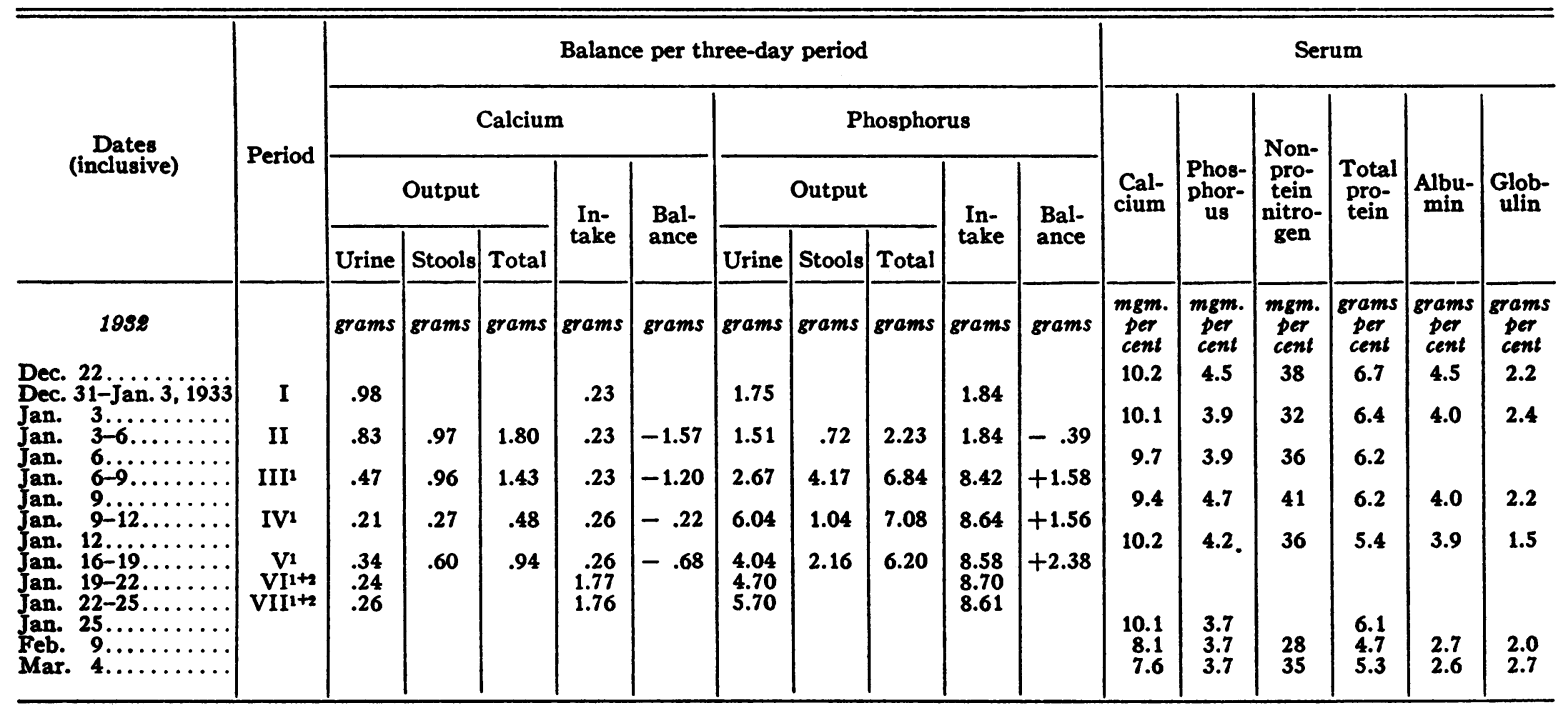

16.72 grams $\mathrm{P}$ per three-day period added as $\mathrm{NaH}_{2} \mathrm{PO}_{4} \cdot \mathrm{H}_{2} \mathrm{O}$.

21.50 gram Ca per three-day period added as $\mathrm{Ca}\left(\mathrm{C}_{3} \mathrm{H}_{5} \mathrm{O}_{3}\right)_{2} .5 \mathrm{H}_{2} \mathrm{O}$.

During four-day interval between Periods IV and $\mathrm{V}$ diet and medications continued as in Period IV.

each other and with similar studies in the literature the figures for all the balance experiments have been calculated for three-day periods.

The patterns of the concentrations of calcium, phosphorus and proteins in the sera of the four patients varied widely. In Case 1 the hypercalcemia was accompanied by hyperproteinemia while the terminal elevation of serum calcium in Case 3 occurred with a slightly diminished concentration of serum proteins. In all cases serum phosphorus and proteins fluctuated considerably, but the changes apparently bore no relation to serum calcium except in Case 4 where a progressive decrease in the serum proteins was reflected in a diminishing concentration of calcium. All of the patients excreted excessive amounts of calcium in the urine during the control periods. In the first three cases the diets were designed to ap- 
proximate the customary intake of calcium and phosphorus. The urinary excretion of calcium by normal individuals taking the same diets varied from 0.15 gram to 0.70 gram per three-day period, with an average of 0.50 gram for eleven experiments. These values for normal calcinuria are consistent with reports in the literature (13, $35)$. The calcinuria of the patients with myeloma was unequivocally excessive. Although this is one of the metabolic findings which has been alleged to be of pathognomonic significance in the diagnosis of generalized osteitis fibrosa cystica, it is not infrequently observed in multiple myeloma $(11,13,16,27,38)$. The urinary excretion of calcium by Case 4 with Paget's disease was strikingly in excess of that of normal individuals on low calcium diets. With an identical diet a control subject who exhibited no disturbances of calcium and phosphorus metabolism excreted 0.30 gram of calcium per three-day period in the urine (average of seven periods). The calcinuria of the control subject is comparable with that of several normal individuals in the series studied by Bauer, Albright and Aub (8), although it slightly exceeds the average of the series (0.19 gram per three-day period). Excessive calcinuria in Paget's disease is exceptional to the rule (34) but not without precedent (32) in the reported studies of the disease.

It has been noted that ingestion of extra phosphorus appears to have a very considerable effect on the urinary excretion of calcium $(2,13)$. In hyperparathyroidism the diminution of calcinuria during periods in which phosphate was fed has been construed to support Albright's theory of the functional pathology of that disease (vide Discussion). In Case 1 no definite association between calcinuria and intake of phosphorus can be inferred while in Case 2 the reduction of calcinuria is not large enough to be entirely convincing and may have occurred quite independently of the influence of the extra phosphorus ingested. The brevity of the studies necessitated by the seriousness of the patient's condition precludes any definite conclusions regarding the effectiveness of phosphate administration. The calcium in the urine of Case 4 strikingly and promptly fell when phosphate was added to the diet, and after a slight lag fecal calcium excretion likewise diminished. Thereafter the total calcium balance was maintained within normal limits. Even when the intake of calcium was increased 0.50 gram daily by the ingestion of calcium lactate the calcinuria remained small. Unfortunately, the syndrome of transverse myelitis supervened during Period VI and the patient became incontinent of feces, but urine collections were complete up to the end of Period VII. Desired observations of the effects of withholding phosphate at this time were impossible because of the difficulty of collecting specimens. In the control subject who received the same diet as Case 4 the ingestion of phosphate resulted in a slight diminution of the calcinuria ( 0.30 gram to 0.16 gram per three-day period) which was reflected in a reduced negative calcium balance. In both subjects studied with a low calcium diet, Case 4 whose calcinuria was strikingly reduced by ingestion of phosphate and the control subject whose calcinuria at a lower basal level was only slightly diminished by the same amount of phosphate, the economy of calcium was effected without any significant change in the chemical pattern of the serum.

\section{DISCUSSION}

Hypercalcemia may and frequently does occur in pathological conditions when there is no anatomical evidence of an increase in the activity of the parathyroid tissue. In multiple myeloma it may or may not be associated with an increase in serum proteins. In most of the reported cases serum proteins are not recorded. The literature yields twenty-three instances of hypercalcemia in multiple myeloma where serum proteins were simultaneously determined. In fourteen of these, hyperproteinemia was observed $(19,22,24,27$, $28,33,37)$ in four hypoproteinemia obtained $(10$, $13,18,19)$ and in five the total serum proteins were normal $(10,19,23,29,39)$. Only four reports of the condition of the parathyroid glands at autopsy have been found in a series of over thirty case reports of multiple myeloma with hypercalcemia. Three of these $(14,24,33)$ specify that the parathyroid glands were normal. The finding of 3 moderately enlarged glands in the case presented by Bulger et al. (13) is unique.

In view of the high concentration of proteins in the serum of Case 1 of the present report it is reasonable to assume that part of the total increase in the serum calcium was due to an increase 
in the protein bound fraction. Herbert's (22) filtration studies with serum containing comparably elevated concentrations of protein and calcium (Patient A Ho) indicate that both diffusible and non-diffusible fractions of the serum calcium share in the total increase. In Case 3 the terminal elevation of serum calcium was not accompanied by any increase in the serum proteins; nevertheless both protein-bound and filtrable calcium were increased proportionately. When the serum contained $17.7 \mathrm{mgm}$. of calcium per 100 cc., 55 per cent of the total was ultrafiltrable, a figure which is consistent with the figures for percentage of diffusible calcium in normal sera under similar experimental conditions.

The mechanism of this elevation of serum calcium is quite unexplained. Comparable elevations of serum calcium are occasionally observed in cases of metastatic neoplasm involving bone. Five such cases have been studied in the New Haven Hospital in recent years; the serum proteins varied from 7.6 to 5.3 grams per cent and the serum calcium from 18.5 to $11.6 \mathrm{mgm}$. per cent, the lowest calcium concentrations occurring in the patients with the lowest serum proteins. Gutman (19) found serum calcium values greater than $11.0 \mathrm{mgm}$. per cent in 5 out of 26 cases. Mason and Warren (31) reported a case of metastatic breast cancer with persistent hypercalcemia varying between 17.6 and $12.9 \mathrm{mgm}$. per cent. The excretion of calcium on a low calcium diet was quite within normal limits. In their case a tumor in the neck, thought to be a parathyroid adenoma, proved to be a metastatic nodule from the mammary carcinoma.

There is apparently no correlation between the excessive calcium excretion in the urine and the concentrations of calcium in the sera. The same lack of relationship is obvious in the case (Case 3 ) reported by Bulger et al. (13). It would seem that the excretion of calcium by the kidneys depends on other factors besides the concentration of total calcium in the serum. The economy effected by the ingestion of phosphate without any change in the serum pattern is of especial significance in connection with theories which relate the effects of phosphate administration to the disturbed metabolism of hyperparathyroidism. Albright, Bauer, Claflin and Cockrill (2) studying the effects of phosphate ingestion in patients with hypercalcemia, hypophosphatemia and excessive urinary excretion of both calcium and phosphorus $^{2}$ ascribed the diminution of calcinuria in the first two cases to the lower concentration of calcium in serum which allegedly resulted from the increased concentration of phosphorus. The findings in their third case were at variance with the concept of calcium as a threshold substance. During the first period of phosphate administration to Case 1 of Bulger et al. (13) the data accord with Albright's observations in his first two cases; but in subsequent periods of phosphate feeding, calcinuria diminished while serum calcium gradually increased and serum phosphorus dropped. The studies of Bulger's Case 3 present further evidence that administration of phosphate may affect calcemia and calcinuria quite independently. The mechanism whereby phosphate ingestion alters the urinary excretion of calcium is not clear, but certainly any hypothesis which relates the changes to alterations in the serum pattern fails to account for all the observed facts.

Knowledge regarding the physicochemical state of calcium in serum and the factors controlling its excretion is still fragmentary. That the parathyroid hormone plays a significant part in the regulation of calcium metabolism is clearly established. The significant question would seem to be whether forces other than an excess of parathyroid hormone can cause similar alterations in the metabolic functions. The three cases of myeloma and one of Paget's disease presented in this report constitute evidence that hypercalcemia and hypercalcinuria may occur in patients with normal parathyroid glands. While "secondary hyperparathyroidism" offers an attractive explanation for the hypercalcemia and hypercalcinuria in the rare and exceptional case in which hyperplasia of parathyroid tissue is observed (25) it seems improbable in cases where careful study reveals no anatomic evidence of hyperactivity. Granting all the imperfections in the present knowledge concerning the correlation of anatomic change and metabolic function, at least skepticism is justified

\footnotetext{
2 Parathyroid tumors were subsequently removed from the first two patients (Mr. C. M. and Mrs. N. B.), Cases 6 and 4 ; but the 3d patient, Mrs. M. D., is not included in the review of seventeen cases seen at Massachusetts General Hospital (1).
} 
when hyperfunction is ascribed to glands which are grossly and microscopically normal.

\section{SUMMARY AND CONCLUSIONS}

Studies in three cases of multiple myeloma and one of Paget's disease exhibiting the alleged metabolic criteria of hyperparathyroidism are presented. The parathyroid glands in each case were normal. The excretion of calcium in the urine could not be correlated with its concentration in serum. Ingestion of phosphate diminished calcinuria without changing the chemical pattern of the serum.

\section{BIBLIOGRAPHY}

1. Albright, F., Aub, J. C., and Bauer, W., Hyperparathyroidism. J. A. M. A., 1934, 102, 1276.

2. Albright, F., Bauer, W., Claflin, D., and Cockrill, J. R., Studies in parathyroid physiology. III. The effect of phosphate ingestion in clinical hyperparathyroidism. J. Clin. Invest., 1932, 11, 411.

3. Ballin, M., Parathyroidism in reference to orthopaedic surgery. J. Bone and Joint Surg., 1933, 15, 120.

4. Ballin, M., Parathyroidism. Ann. Surg., 1932, 96, 649.

5. Ballin, M., and Morse, P. F., Parathyroidism. Am. J. Surg., 1931, 12, 403.

6. Ballin, M., and Morse, P. F., Parathyroidism and parathyroidectomy. Ann. Surg., 1931, 94, 592.

7. Bauer, W., Hyperparathyroidism: A distinct disease entity. J. Bone and Joint Surg., 1933, 15, 135.

8. Bauer, W., Albright, F., and Aub, J. C., Studies of calcium and phosphorus metabolism. II. The calcium excretion of normal individuals on a low calcium diet, also data on a case of pregnancy. J. Chin. Invest., 1929, 7, 75.

9. Bauer, W., and Aub, J. C., Studies of inorganic salt metabolism. I. The ward routine and methods. J. Am. Dietet. A., 1927, 3, 106.

10. Bell, E. T., Renal lesions associated with multiple myeloma. Am. J. Path., 1933, 9, 393.

11. Blatherwick, N. R., Calcium and Bence-Jones protein excretion in multiple myeloma. Am. J. M. Sc., 1916, 151, 432.

12. Bruckman, F. S., D'Esopo, L. M., and Peters, J. P., The plasma proteins in relation to blood hydration. IV. Malnutrition and the serum proteins. J. Clin. Invest., 1930, 8, 577.

13. Bulger, H. A., Dixon, H. H., Barr, D. P., and Shregardus, $O$., The functional pathology of hyperparathyroidism. J. Clin. Invest., 1930, 9, 143.

14. Caylor, H. D., and Nickel, A. C., Multiple myeloma simulating hyperparathyroidism. Ann. Surg., 1933, 97, 823.
15. Compere, E. L., The rôle of the parathyroid glands in diseases associated with demineralization of the human skeleton. J. Bone and Joint Surg., 1933, 15,142 .

16. Currie, R. A., Case of Bence-Jones proteinuria with a note on the urinary excretion of the mineral elements. Glasgow M. J., 1927, 107, 31.

17. Fiske, C. H., and Subbarow, Y., The colorimetric determination of phosphorus. J. Biol. Chem., 1925, 66,375 .

18. Freund, R., and Magnus-Levy, A., Multiple myelome. V. Uber Besonderheiten der Blutzusammensetzung (Eigenhemmung, Koagulation, Hyperproteinämie usw). Ztschr. f. klin. Med., 1932, 121, 1.

19. Gutman, A., Personal communication.

20. Hald, P. M., The determination of the bases of serum and whole blood. J. Biol. Chem., 1933, 103, 471.

21. Hannon, R. R., Shorr, E., McClellan, W. S., and DuBois, E. F., A case of osteitis fibrosa cystica (osteomalacia?) with evidence of hyperactivity of the parathyroid bodies: Metabolic study I. J. Clin. Invest., 1930, 8, 215.

22. Herbert, F. K., The total and diffusible calcium of serum and the calcium of cerebrospinal fluid in human cases of hypocalcemia and hypercalcemia. Biochem. J., 1933, 27, 1978.

23. Hewitt, L. F., Urine proteins in nephrosis, pregnancy and myelomatosis. Lancet, 1929, 1, 66.

24. Jores, A., Beitrag zur differentialdiagnose des multiplen Myeloms und der Ostitis Fibrosa Generalisata. Klin. Wchnschr., 1931, 10, 2352.

25. Klemperer, P., Parathyroid hyperplasia and bone destruction in generalized carcinomatosis. Surg. Gynec. and Obst., 1923, 36, 11.

26. Klumpp, T. G., The determination of iron in biological materials. J. Biol. Chem., 1934, 107, 213.

27. Lenshoek, C. H., Over Stoornissen in de Stofwisseling der Mineralen Bij Ostitis Fibrosa Generalisata en bij Multiple Myelomen. Nederl. tijdschr. v. geneesk., 1933, 77, 1193.

28. Magnus-Levy, A., Multiple myelome. VII. Euglobulinämie. Zur Klinik und Pathologie. Amyloidosis. Ztschr. f. klin. Med., 1933, 126, 62.

29. Mainzer, F., Bence-Jonessche Proteinurie und Nierenfunktion. Ztschr. f. klin. Med., 1932, 119, 363.

30. Mandl, F., Klinisches und Experimentelles zur Frage der Lokalisierten und generalisierten Osteitis fibrosa. Arch. f. klin. Chir., 1926, 143, 245.

31. Mason, R. L., and Warren, S., Metastatic carcinoma simulating hyperparathyroidism. Am. J. Path., 1931, 7, 415.

32. Rabinowitch, I. M., Metabolic studies in a case of osteitis deformans. J. Nutrition, 1932, 5, 325.

33. Reiman, H. A., Hyperproteinemia as a cause of autohemagglutination. J. A. M. A., 1932, 99, 1411.

34. Scriver, W. de M., and Venning, E. M., Observations upon the calcium and phosphorus metabolism in certain diseases of bone. J. Clin. Invest., 1934, 13, 139. 
35. Sherman, H. C., Calcium requirement of maintenance in man. J. Biol. Chem., 1920, 44, 21.

36. Sherman, H. C., Chemistry of Food and Nutrition. The Macmillan Co., New York, 1933, 4th ed.

37. Shirer, J. W., Duncan, W., and Haden, R. L., Hyperproteinemia due to Bence-Jones protein in myelomatosis. Arch. Int. Med., 1932, 50, 829.

38. Williams, O. T., Some observations on the nature of the Bence-Jones protein. Biochem. J., 1911, 5, 225.

39. Wirth, W. R., Multiple myeloma. Report of a case. New Orleans M. and S. J., 1932, 84, 698.

\section{APPENDIX}

\section{Protocols of Cases}

Case 1, J. B., a man of 60 , was admitted to the New Haven Hospital July 18, 1930. In 1927 he had developed extreme weakness, anorexia and loss of weight which had lasted about a year. The relation of this to the condition for which he was finally admitted was not clear. In 1928 he had experienced nagging pain in the lower abdomen, and tarry stools. In June 1929 he became aware of increasing pains in the chest and back, weakness and loss of weight. The following October a number of teeth were extracted with subsequent intractable hemorrhage. In another hospital he was found to have a severe anemia with a high color index. Emaciation and dehydration were noted and there was tenderness over the costal cartilages and the rib margins and evident collapse of one vertebra. X-ray revealed marked decalcification of the lumbar vertebrae, while the skull, left femur and right forearm appeared normal. During December, pains in the back and ribs became more severe and extreme sacro-iliac pain developed. The patient survived an intercurrent pneumonia. The anemia did not improve in spite of intensive liver therapy. A course of parathyroid extract distinctly aggravated his symptoms.

On admission to the New Haven Hospital in July 1930, he was greatly emaciated and extremely weak. The blood pressure was 120/80. There was evident shortening and flattening of the lumbar spine and a severe anemia. X-ray showed decalcification of all the vertebrae and, to a lesser extent, of the ribs and pelvis, with slight rarefaction of the femora and skull, but none of the tibiae and fibulae. Three vertebrae had collapsed. The hemogram was typical of myelophthisic anemia. The urine contained a faint trace of albumin and frequent white blood cells and hyaline casts. Repeated tests for Bence-Jones protein in the urine were negative.

His general condition was desperate, feeding extremely difficult and he deteriorated with great rapidity. August 4th he had the first of a series of fractures of the ribs with steadily increasing deformity of the chest. January 21 he climbed out of bed in delirium and snapped his right femur. X-rays revealed increasing rarefaction of all bones, including the skull. During the last few days of January, the patient became increasingly irrational, and incontinent of feces and urine. His blood pressure dropped to $100 / 70$ before death which occurred February $3,1931$.

Autopsy. The neck and mediastinum were carefully searched for parathyroid tumor. All four of the small parathyroid glands which were removed showed normal microscopical structure.

Anatomical diagnosis. Diffuse myeloma involving the bone marrow of the vertebral bodies, ribs, sternum and femurs, with erosion of the bone cortex and metastases to lymph nodes, spleen, liver and kidney; anemia; emaciation; diffuse pneumonia (right lower); pülmonary arteritis with thrombosis; vegetative mitral endocarditis.

Case 2, A. C., a man of 52, was admitted to the New Haven Hospital December 7, 1933. Four months earlier he had begun to suffer from pain in the back and a month later had developed pains and tenderness in the ribs, accompanied by weakness and loss of weight.

On admission he appeared weak and emaciated. There was irregularity in the vertebral alignment, with tenderness over the spine and ribs. Several fusiform swellings were palpable in the ribs and a firm slightly tender mass was felt in the inferior portion of the right scapula. $\mathrm{X}$-ray revealed rather general decalcification of the bones with widening of the medullary cavities and in addition focal areas of more intense rarefaction in many of the long bones, and collapse of at least one vertebra. The blood picture indicated a myelophthisic anemia. The urine contained large amounts of Bence-Jones protein (12 to 20 grams per day) without albumin. Biopsy of a rib confirmed the diagnosis of diffuse myelomatosis.

In the hope of checking or reversing the process of decalcification a parathyroidectomy was performed on January 5 by Doctor Samuel Harvey. Extensive search revealed three small parathyroid glands which were removed. No parathyroid tumor was found. The microscopic structure of the extirpated parathyroids was normal. The patient developed pneumonia and died three days after operation. Permission for autopsy could not be obtained. The serum calcium just before death was found to be normal.

Case 3, F. A., a man of 34 , was admitted to the New Haven Hospital April 16, 1934. Six months earlier he had developed pain in his back after a slight wrench. This had gradually and steadily increased in intensity and extent until it involved the whole back and the ribs. X-ray on March 29 had revealed collapse of three lumbar vertebrae with decalcification of the spine, irregular decalcification of the pelvis and ribs, but nothing abnor$\mathrm{mal}$ in the skull.

On admission his nutrition was fairly good but muscular weakness was evident and movements were guarded because of pain in the back. There was tenderness over the ribs and the lower dorsal and the lumbar spines. There was a moderate hyperchromic anemia and, as the condition progressed, increasing numbers of myelocytes 
were found in the spread. The urine contained neither albumin nor Bence-Jones protein, and the formed elements of the sediment remained consistently normal. A biopsy of rib on April 17 confirmed the diagnosis of myeloma. The abnormal cells were identified as endothelial in type.

The patient deteriorated steadily, developing fractures of many ribs and of the pelvis and increasing deformities until his death which occurred on June 22, 1934.

At autopsy the neck and mediastinum were carefully dissected, but no parathyroid tumor was discovered. The microscopic structure of the small parathyroid glands which were found was normal.

Case 4, W. C., a man of 64, was admitted to the New Haven Hospital December 19, 1932. For six or seven years he had suffered from pains in the back which were called lumbago. In August of 1932 he had had a more severe attack which had persisted, increasing in severity, until his admission, by which time he was confined almost entirely to a chair because of inability to stand upright or to lie down. The pains had radiated down the right sciatic nerve and had later involved the left leg. Shortly before admission he had noticed tender lumps on his head and pain in the right shoulder. Severe headaches had become a prominent symptom.

On admission his chief complaints were headache, pain about the right orbit, pain across the buttocks, down the legs and boring into the shins, and urinary troubles which he referred to an old stricture. He was markedly emaciated. There was tenderness over the spine and striking atrophy of the muscles of the legs. Numerous tender lumps were present over the skull and one on the left clavicle.

$\mathrm{X}$-rays revealed the characteristic lesions of Paget's disease in the spine, pelvis and femora. There was more than the usual rarefaction with patchy increases of density. There was moderate secondary anemia; no myelocytes were seen in the spreads. The urine contained albumin but no Bence-Jones protein.

The lumps in the skull increased steadily in size and new ones appeared over other bones. A tumor mass growing in the right orbit gradually extruded the eye from its socket. In the latter part of January he developed paralysis of both lower extremities and of the sphincters and soon after this signs of cranial nerve lesions appeared, presumably from the tumors of the skull. On February 8 pathological fracture of the right femur occurred. X-ray revealed that there was almost complete decalcification of the cortex of the upper half of the femur, the shadow cast being more like soft tissue than bone. Deterioration was rapid and death occurred on March 8, 1933.

Autopsy. Careful dissection of the neck and mediastinum disclosed parathyroid glands of normal size which on section proved to have normal microscopic structure. No parathyroid tumor was found.

Anatomical diagnosis. A. Nodular thickening, thinning and decalcification of bones of skull, femurs, tibiae, clavicles, sternum, ribs, scapulae, vertebrae and pelvis; a nodule in orbital plate with compression of the ocular bulb; bone nodules of pleura (left lower lobe) ; compression of spinal cord (5th thoracic vertebra); transverse myelitis ; recent operation (suprapubic cystotomy) ; fracture of right femur; exophthalmos (right) ; splenomegaly. B. Generalized arteriosclerosis with especial involvement of coronary arteries; hydrothorax, hydropericardium.

Subsidiary: Fibrous pleural adhesions (bilateral); emphysema (bilateral). Clinically-Paget's disease. 